\title{
Analysis of the level of depression in perimenopausal women according to sociodemographic characteristics
}

\begin{abstract}
Introduction. Historically, perimenopausal period was thought to be associated with mood disorders. Despite many studies, the relationship between menopause and depressed mood has not been fully explained.

Aim. The objective of the study was analysis of the level of intensity of depression among women at perimenopausal age according to sociodemographic characteristics.

Material and methods. The study covered 268 perimenopausal women who reported to outpatient departments in the city of Lublin. The criteria for the qualification of women into the study group were: age 45-55 years, lack of mental disorders and lack of diseases requiring hospitalization during the period of study. The study was conducted with the method of a diagnostic survey with the use of the Beck Depression Inventory (BDI) and a questionnaire designed by the authors in order to collect demographic data.

Results. The mean BDI values obtained in the presented study according to respondents' age and monthly income showed the lack of depression or mild depression in the group of the women examined. In addition, the mean level of depression according to marital status confirmed the lack of depression in the group of married women, whereas mild depression in the group of those who were single.

Conclusions. Analysis of the results of the study indicated that age and marital status were not related with the respondents' level of depression. Women who possessed a university education had a lower level of depression, compared to those who had elementary/elementary vocational or secondary school education level. Women whose material standard was higher had a lower level of depression. Women who have a poor material standard and lower level of education should be covered by a special psycho-prophylactic care.
\end{abstract}

Keywords: perimenopause, depression, sociodemographic characteristics.

DOI: $10.1515 /$ pjph-2017-0004

\section{INTRODUCTION}

The perimenopausal period has been traditionally associated with mood disorders. For a long time, reports have been available concerning the aetiology and pathogenesis of depression syndromes at perimenopausal age, as well as their classification and terminology. Kraepelin and Bleuler [1] - the well-known founders of nosology in psychiatry - introduced the term 'involutional melancholia', understood as depression typical for women at menopausal age. At present, this is a historical term which no longer features in the psychiatric terminology, because the clinical image of depression in menopausal women does not differ much from the characteristic of classic affective diseases [1-3].

Although the problem was undertaken by many researchers, the relationship between states of depression and menopause has not been fully explained. Due to the lack of unequivocal clinical studies confirming the presence of a relationship between menopause and affective disorders, the American College of Obstetricians and Gynaecologists issued a statement confirming that menopause is not related with an increased risk of occurrence of depressive disorders in women [4]. However, there are reports which suggest that the perimenopausal period is associated with an increased risk of depression development [5-8].

\section{AIM}

The objective of the study was analysis of the level of depression severity among perimenopausal women according to selected sociodemographic data.

\section{MATERIAL AND METHOD}

The study covered 268 women aged $45-55$ who reported to outpatient departments in the city of Lublin. The criteria

\footnotetext{
${ }^{1}$ Department of Obstetrics, Gynaecology and Obstetric-Gynaecological Nursing, Medical University, Lublin, Poland

${ }^{2}$ Chair and Clinic of Gynaecology and Gynaecological Endocrinology, Medical University, Lublin, Poland

${ }^{3}$ Department of Gynaecology and Obstetrics, Cardinal Stefan Wyszyński Regional Specialist Hospital, Lublin, Poland
} 
for qualification of women into the study group were: age 4555 years, lack of mental disorders and diseases requiring rehabilitation during the period of conducting the research. Women with iatrogenic menopause were excluded from the study. The study was voluntary and anonymous. The women examined expressed their consent to participate after previous explanation of the objective and the course of the study.

The project obtained a positive opinion from the Bioethics Committee at the Medical University in Lublin (No. KE0254/6/2008).

The study was conducted with the method of a diagnostic survey using the Beck Depression Inventory (BDI) and a questionnaire designed by the authors in order to collect the demographic data.

Beck Depression Inventory (BDI) is an instrument for the assessment of the intensity of depression. According to the authors, this Inventory allows the measurement of severity of depression in those who are ill, and enables the differentiation of healthy individuals from those who are ill, showing symptoms of depression [9]. The scale consists of 21 items. The sum of scores obtained in evaluations of individual symptoms is a numerical value of the level of depression which remains within the range of $0-63$ scores. While interpreting the results of the presented study, an evaluation was performed of the intensity of depressive feelings according to the numerical value of the severity of depression. The following criteria of evaluation of the severity of depressive feelings were adopted in the study: 0-9 scores indicates the lack of symptoms of depression, 10-16 - scores mild intensity of depression, 17-29 scores - moderate intensity of depression, $>30$ scores - severe depression [10].

Two age groups were distinguished in the study: the first group consisted of $141(52.61 \%)$ women aged up to 50, while the second group consisted of $127(47.39 \%)$ respondents aged over 50. As many as $164(61.19 \%)$ women in the study were urban inhabitants, whereas 104 (38.81\%) respondents lived in rural areas. The largest number of the women examined had secondary school education $(n=149 ; 55.60 \%$, while $24.63 \%$, $(n=66)$ university education, and $19.78 \%(n=53)$ elementary/ elementary vocational education level. Based on the collected data, it was found that the majority of women in the study were married $(n=210 ; 78.36 \%)$. Every fifth woman in the study $(\mathrm{n}=58 ; 21.64 \%)$ was single (unmarried, widowed, divorced). The monthly income obtained by the perimenopausal examined women was the most often within the range 1.001-2.000 PLN ( $\mathrm{n}=145 ; 54.10 \%)$, it was rarely higher than 2.000 PLN $(\mathrm{n}=48 ; 17.91 \%)$, while in $27.99 \%(\mathrm{n}=75)$ of respondents it did not exceed 1.000 PLN.

Statistical analysis of the collected data was performed using the software SPSS/PC. Statistical significance of the relationships between variables was investigated by means of t Student test. A 5\% error was accepted, the $p$ values $p<0.05$ were considered statistically significant.

\section{RESULTS}

Figure 1 presents an overall analysis of the level of depression (BDI) in the group of examined perimenopausal women.

Based on the results of the presented study it was confirmed that $55.60 \%,(n=149)$ of respondents had no symptoms of depression, while $30.97 \%$, $(n=83)$ had mild, $7.84 \%$, $(n=21)$ - moderate, and $5.60 \%(n=15)-$ severe symptoms of depression. The mean value of the level of depression in the group examined was 10.18 \pm 7.96 .

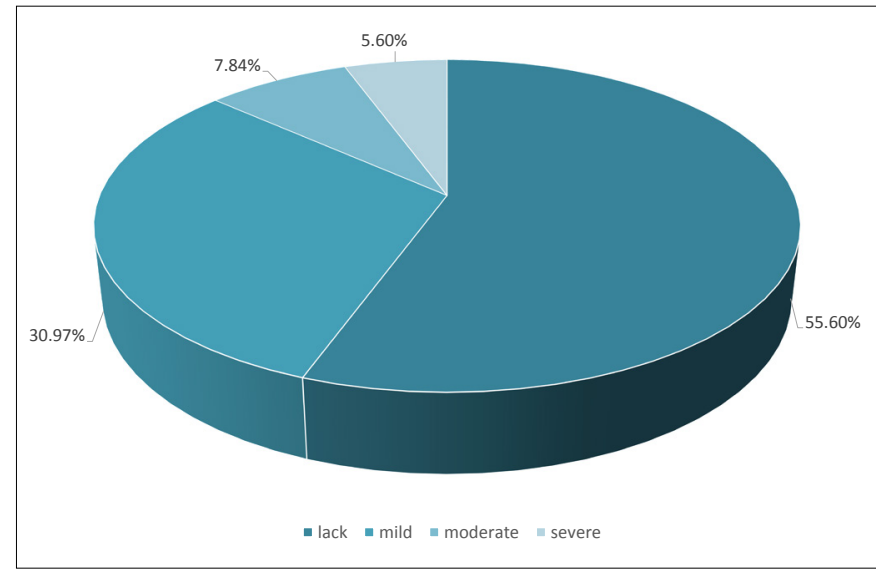

FIGURE 1. Percentage of respondents according to the level of depression.

Table 1 presents the analysis of the level of depression (BDI) among perimenopausal women according to the respondents' age.

TABLE 1. Relationship between the level of depression (BDI) in perimenopausal women according to age.

\begin{tabular}{lccccccc}
\hline \hline \multicolumn{1}{c}{ Age } & $\mathrm{n}$ & $\mathrm{M}$ & $\mathrm{Min}$ & $\mathrm{Max}$ & $\mathrm{SD}$ & Kurtosis & Skewness \\
\hline Up to 50 & 141 & 9.62 & 0.00 & 40.00 & 7.64 & 1.00 & 1.18 \\
\hline Over 50 & 127 & 10.80 & 0.00 & 32.00 & 8.29 & 0.82 & -0.11 \\
\hline $\mathrm{t}$ & \multicolumn{7}{c}{-1.20} \\
$\mathrm{p}$ & & \multicolumn{7}{c}{0.23} \\
\hline
\end{tabular}

$\mathrm{n}$ - number of respondents, $\mathrm{M}$ - arithmetic mean, Min - minimum, Max - maximum, $\mathrm{SD}-$ standard deviation, $\mathrm{t}$ - result of t-Student test, $\mathrm{p}-$ level of probability

The mean value of the level of depression obtained using the Beck Depression Inventory (BDI) in the group of women aged up to 50 was 9.62 and was lower than this among women aged over 50 (10.80). However, no statistically significant differences in the level of depression were observed between the groups $(p>0.05)$. The mean values of the level of depression (BDI) according to respondents' age found in own study indicated the lack of depression or mild depression in the group of examined women.

No relationship was observed between the level of depression among perimenopausal women in the study and their age.

Table 2 presents correlation between the respondents' level of depression (BDI) and education level.

TABLE 2. Relationship between the level of depression (BDI) and education level of women at perimenopausal age.

\begin{tabular}{|c|c|c|c|c|c|c|c|}
\hline Education level & $\mathbf{n}$ & M & Min & Max & SD & 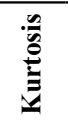 & 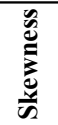 \\
\hline $\begin{array}{l}\text { Elementary/elementary } \\
\text { vocational }\end{array}$ & 53 & 12.49 & 0.00 & 40.00 & 8.75 & 0.96 & 0.60 \\
\hline Secondary school & 149 & 10.34 & 0.00 & 33.00 & 7.63 & 0.72 & 0.01 \\
\hline University & 66 & 7.95 & 0.00 & 32.00 & 7.56 & 1.32 & 1.52 \\
\hline Groups compared & & $\mathrm{t}$ & & \multicolumn{4}{|c|}{$\mathrm{p}$} \\
\hline $\begin{array}{l}\text { Elementary/elementary } \\
\text { vocational - secondary school }\end{array}$ & & 1.69 & & \multicolumn{4}{|c|}{0.09} \\
\hline $\begin{array}{l}\text { Elementary/elementary } \\
\text { vocational - university }\end{array}$ & \multicolumn{3}{|c|}{3.03} & \multicolumn{4}{|c|}{0.003} \\
\hline Secondary school - university & \multicolumn{3}{|c|}{2.12} & \multicolumn{4}{|c|}{0.03} \\
\hline
\end{tabular}

$\mathrm{n}$ - number of respondents, $\mathrm{M}$ - arithmetic mean, Min - minimum, Max - maximum, $\mathrm{SD}$ - standard deviation, $\mathrm{t}$ - result of $\mathrm{t}$-Student test, $\mathrm{p}-$ level of probability 
The mean value of the level of depression among women who had a university education level was 7.95 and was significantly lower $(\mathrm{p}=0.03)$ than the value 10.34 observed among women who had secondary school education. Among the respondents with elementary/elementary vocational education, the BDI value was 12.49 and was significantly higher $(\mathrm{p}=0.003)$ compared to those who had a university education $(p=0.003)$. Statistical analysis showed no significant differences between respondents with elementary/elementary vocational education and those who had secondary school education $(p=0.09)$. Considering the mean values of the depression level according to education level, the group of respondents with elementary/elementary vocational and secondary school education remained within the range of mild depression, whereas the group of women who had university education level - within the range indicating the lack of depression.

The study showed a relationship between the level of depression among perimenopausal women and education, this level being higher in the group of women who had elementary/ elementary vocational and secondary school education, compared to those who possessed a university education.

Table 3 shows the analysis of the level of depression (BDI) according to marital status of women at perimenopausal age.

TABLE 3. Relationship between the level of depression (BDI) and marital status of perimenopausal women.

\begin{tabular}{lccccccc}
\hline \multicolumn{1}{c}{ Marital status } & $\mathbf{n}$ & M & Min & Max & SD & Kurtosis & Skewness \\
\hline Married & 210 & 9.99 & 0.00 & 40.00 & 7.89 & 0.96 & 0.60 \\
\hline Single & 58 & 10.88 & 0.00 & 33.00 & 8.23 & 0.75 & 0.17 \\
\hline $\mathrm{t}$ & & & & 0.76 & & \\
\hline $\mathrm{p}$ & & & \multicolumn{5}{c}{0.45} \\
\hline
\end{tabular}

$\mathrm{n}$ - number of respondents, $\mathrm{M}$ - arithmetic mean, Min - minimum, Max - maximum, $\mathrm{SD}$ - standard deviation, $\mathrm{t}$ - result of $\mathrm{t}-\mathrm{Student}$ test, $\mathrm{p}-$ level of probability

The mean value of the level of depression (BDI) among married women was 9.99, whereas in the group of single women -10.88 . In the presented study no statistically significant differences were observed between the mean values obtained ( $p>0.05)$. The mean BDI values found in own study according to marital status showed the lack of depression in the group of married women and indicated a mild depression among single women.

The study confirmed that marital status did not determine the respondents' level of depression (BDI).

Table 4 presents the analysis of the level of depression (BDI) according to the monthly income obtained by perimenopausal women.

TABLE 4. Relationship between the level of depression (BDI) and monthly income obtained by respondents.

\begin{tabular}{lccccccc}
\hline \hline \multicolumn{1}{c}{ Income } & n & M & Min & Max & SD & Kurtosis & Skewness \\
\hline up to 1,000 PLN & 75 & 12.60 & 0.00 & 40.00 & 9.06 & 0.75 & 0.06 \\
\hline 1,001-2,000 PLN & 145 & 9.42 & 0.00 & 33.00 & 7.52 & 0.90 & 0.32 \\
\hline Over 2,000 PLN & 48 & 8.69 & 0.00 & 27.00 & 6.66 & 0.74 & 0.12 \\
\hline Groups compared & & $\mathrm{t}$ & & & & $\mathrm{p}$ & \\
\hline $\begin{array}{l}\text { Up to 1,000 PLN - } \\
\text { 1,001-2,000 PLN }\end{array}$ & 2.77 & & & & 0.006 & \\
\hline $\begin{array}{l}\text { Up to 1,000 PLN - } \\
\text { Over 2,000 PLN }\end{array}$ & & 2.58 & & & & 0.01 & \\
\hline $\begin{array}{l}\text { 1,001-2,000 PLN - } \\
\text { Over 2,000 PLN }\end{array}$ & 0.60 & & & & 0.55 & \\
\hline
\end{tabular}

$\mathrm{n}$ - number of respondents, $\mathrm{M}$ - arithmetic mean, Min - minimum, Max - maximum, $\mathrm{SD}-$ standard deviation, $\mathrm{t}-$ result of $\mathrm{t}-\mathrm{Student}$ test, $\mathrm{p}-$ level of probability
The mean value of the Beck Depression Inventory (BDI) in the group of women obtaining an income exceeding 2,000 PLN was 8.69 and was significantly lower $(p=0.01)$ than in the group of women who had an income below 1.000 PLN (12.60). In the group of respondents whose income ranged within $1.001-2000$ PLN the level of depression was 9.42 and was significantly lower $(\mathrm{p}=0.006)$ compared to the BDI value in the group of women who had an income up to 1.000 PLN. Statistical analysis performed showed no statistically significant differences between the group of respondents who had the highest income and those with an income of 1.001 2000 PLN $(p=0.55)$. The mean values of the level of depression (BDI) according to monthly income indicated the lack of depression or a mild depression among the women in the study. A relationship was observed between the respondents' monthly income and the level of depression, this level being lower in the group of women who had an income exceeding 2.000 PLN, compared to those with an income below 1.000 PLN and an income within the range 1.001 2.000 PLN.

\section{DISCUSSION}

Depression occurs twice as often in females than males [5,7,11-13]. In Krogulski's opinion [14], depressive disorders which require treatment and may be classified according to the ICD-10, concern $20-30 \%$ of women at perimenopausal age and $90 \%$ of them experience mood disorders such as: irritability, emotional liability and difficulties with concentrating. Nevertheless, the studies carried out in Poland by Wojnar et al. [12] indicated that $19.1 \%$ of women aged $45-55$ suffer from depressive disorders.

In the relevant literature there are reports concerning risk factors and hypotheses which explain the susceptibility of perimenopausal women to the development of depression. Bielawska-Batorowicz [3] reported that biological and psychosocial factors are among the fundamental conditionings for the occurrence of depression during perimenopause.

In the presented study an attempt was also undertaken to assess the level of depression according to the respondents' sociodemographic characteristics such as: age, education level, marital status and monthly income.

The study confirmed that the occurrence of the depression symptoms among perimenopausal women does not depend on age. Thus, age did not determine the level of depression in the examined group of women. In the literature available no reports have been found concerning the correlation between the level of depression and age in the group of women at perimenopausal age. Only Jagielska et al. [15] analyzed the relationship between the level of intensity of depression and age of a woman at last menstrual period. These researchers reported that the relationship was highly significant statistically.

According to Hunter and Rendall [16], the occurrence of depression during perimenopause is more strongly conditioned by psychosocial than hormonal factors. The factors which, according to the researchers, condition the development of depression are the following: social problems, education level, occupational activity, past psychological problems, poor state of health, stressful life events and previous living conditions. Similar opinions were presented by Llaneza P. et al. [17], who indicated stress, education level, ethnic origin and marital status as important predictors of depressive disorders in women at perimenopausal age. 
The presented study shows that education determined the level of depression in perimenopausal women. In the group of women who had elementary/elementary vocational education and secondary school education, the level of depression was higher than that found in the group of women who had a university education. The mean BDI values according to education, place the group of respondents with elementary/elementary vocational and secondary school education within the range of mild depression, and the group of those who had a university education level - within the range of values indicating lack of depression. In addition, the study confirmed that monthly income also determined the level of depression among the examined women, this level being lower among women who had an income exceeding 2.000 PLN, compared to those obtaining an income below 2.000 PLN. An increase in the mean BDI value accompanied by a decrease in respondents' education level and income is consistent with the studies by Choi et al. [18], who found a relationship between demographic factors, such as education or income and depression. The researchers reported that a university education level correlated with the lowest level of depression. Choi et al. [18] reported that education is an important resource which facilitates adaptation to the conditions of the external environment. Moreover, Kessler et al. [19], Llanesa et al. [17] and Humeniuk et al. [20] indicated the level of education and income as demographic characteristics exerting a considerable effect on the occurrence of depression in women at perimenopausal age. Similarly, the results of studies by Soares et al [21] showed that low socioeconomic status was one of the factors triggering depression in women.

The results of the presented study confirm that poor material standard and lower education level may be considered as predictors of the development of depression in women at perimenopausal age. These results indicate that providing women who have a lower education level and poor material standard with special psychoprophylactic care may lead to a decrease in the frequency of depression occurrence in perimenopausal women and to an improvement in the quality of their lives.

In the literature available, some researchers [20,22,23] indicated the lack of a partner as a risk factor of the development of depression in women at perimenopausal age. The results obtained in the presented study are inconsistent with the reports by the above-mentioned researchers. Despite higher mean values of the level of depression observed in the group of single women compared to those who were married, statistical analysis did not show any significant differences between the mean values of the level of depression found in the compared groups of women $(p>0.05)$.

Summing up, the results of own study concerning the conditioning of the depression occurrence during perimenopause, it should be presumed that due to an increased risk of the occurrence of depression, women who have poor material standard and low education level should be provided with special psychoprophylactic care. The results obtained indicate that it is justifiable to evaluate mood disorders among women at perimenopausal age. This may allow the selection of a group of women who require an early undertaking of psychotherapeutic actions in order to prevent the development of depression and to improve the quality of life.

\section{CONCLUSIONS}

1. Sociodemographic factors, such as age and marital status, did not determine the respondents' level of depression.

2. Women with a university education had a lower level of depression, compared to those with elementary/elementary vocational and secondary school education.
3. Respondents whose material standard was higher had a lower level of depression.

4. Women who have poor material standard and low education level should be provided special psychoprophylactic care.

\section{REFERENCES}

1. Kotrys K. Depresja u kobiet - wybrane aspekty. Lekarz. 2004;8/9:86-92.

2. Krogulski S, Woźniak P, Lipińska-Szałek A. Depresje w okresie menopauzalnym - rozpowszechnienie, klasyfikacja, terminologia. Ginekol Pol. 2003;74(2):162-7.

3. Bielawska-Batorowicz E. Koncepcje menopauzy. Część III - ujęcie psychopatologiczne. Prz Menopauz. 2005;5:24-31.

4. Skałba P. Perimenopauza (okres okołomenopauzalny). In: P. Skałba (ed). Hormonalna terapia zastępcza. Warszawa: PZWL; 2004. p. 30-50.

5. Soares CN. Can depression be a menopause-associated risk? BMC Med. 2010;1(8):79.

6. Timur S, Sahin NH. The prevalence of depression symptoms and influencing factors among perimenopausal and postmenopausal women. Menopause. 2010;17(3):545-51.

7. Bromberger JT, Kravitz HM. Mood and menopause: findings from the Study of Women's Health Across the Nation (SWAN) over 10 years. Obstet Gynecol Clin North Am. 2011;38(3):609-25.

8. Gibbs Z, Lee S, Kulkarni J. What factors determine whether a woman becomes depressed during the perimenopause? Arch Womens Ment Health. 2012;15(5):323-32.

9. Beck AT, Ward $\mathrm{CH}$, Mendelson $\mathrm{M}$ et al. An inventory for measuring depression. Arch Gen Psychiatry. 1961;4:53-63.

10. Beck AT, Steer RA. Beck Inventory Manual. The Psychological Corporation. Harcourt Brace \& Co; 1993.

11. Krogulski S, Lipińska-Szałek A. Depresje menopauzalne - nietypowy obraz kliniczny, leczenie. Prz Menopauz. 2004;3:31-8.

12. Wojnar M, Dróżdż W, Araszkiewicz A, et al. Rozpowszechnienie zaburzeń depresyjnych wśród kobiet w wieku okołomenopauzalnym zgłaszających się do lekarzy ginekologów. Psychiatr Pol. 2003;37(5):811-24.

13. Hickkey M, Bryant C, Judd F. Evaluation and management of depressive and anxiety symptoms in midlife. Climacteric. 2012;15(1):3-9.

14. Krogulski S. Depresje menopauzalne. In: T. Pertyński (ed). Diagnostyka i terapia wieku menopauzalnego. Wrocław: Urban \& Partner; 2004. p. 175-87.

15. Jagielska I, Grabiec M, Wolski B, et al. Częstość występowania objawów depresji w przebiegu zespołu klimakterycznego u kobiet w okresie postmenopauzy. Prz Menopauzalny. 2007;3:140-4.

16. Hunter M, Rendall M. Bio-psycho-socio-cultural perspectives on menopause. Best Pract. Res Clin Obstet Gynaecol. 2007;21(2):261-74.

17. Llaneza P, Garcia-Portlla MP, Llaneza-Suarez D, Armott B, Perez-López RF. Depressive disorders and the menopause transition. Maturitas. 2012;71(2):120-30.

18. Choi H, Lee D, Lee K, et al. A structural model of menopausal depression in korean women. Arch Psychiatr Nurs. 2004;18(6):235-42.

19. Kessler RC. Epidemiology of women and depression. J Affect Disord. 2003;74(1):5-13.

20. Humeniuk E, Bojar I, Owoc A, et al. Psychosocial conditioning of depressive disorders in post-menopausal women. Ann Agric Environ Med. 2011;18;2:441-5.

21. Soares CN, Joffe H, Steiner M. Menopause and mood. Clin Obstet Gynec. 2004;47(3):576-91.

22. Schmidt PJ. Mood, depression, and reproductive hormones in the menopausal transition. Am J Med. 2005;118(12) Suppl. 2:545-85.

23. Harsh VL, Rubinow DR, Schmidt PJ. Czy zmiany zachodzace w okresie okolomenopauzalnym mogą być przyczyną depresji? Ginekol Dypl. 2008;9:74-9.

\section{Corresponding author}

Katarzyna Kanadys

Department of Midwifery, Gynaecology and Obstetrical-Gynaecological Nursing, Medical University

7 Chodźki St., 20-093 Lublin

E-mail: kanadysk@wp.pl

Tel: +48814486930

\section{Ministerstwo Nauki}

i Szkolnictwa Wyższego

"Wsparcie finansowe zagranicznych recenzentów publikacji w czasopiśmie PJPH" finansowane w ramach umowy 547/P-DUN/2016 ze środków Ministra Nauki i Szkolnictwa Wyższego przeznaczonych na działalność upowszechniającą naukę. 